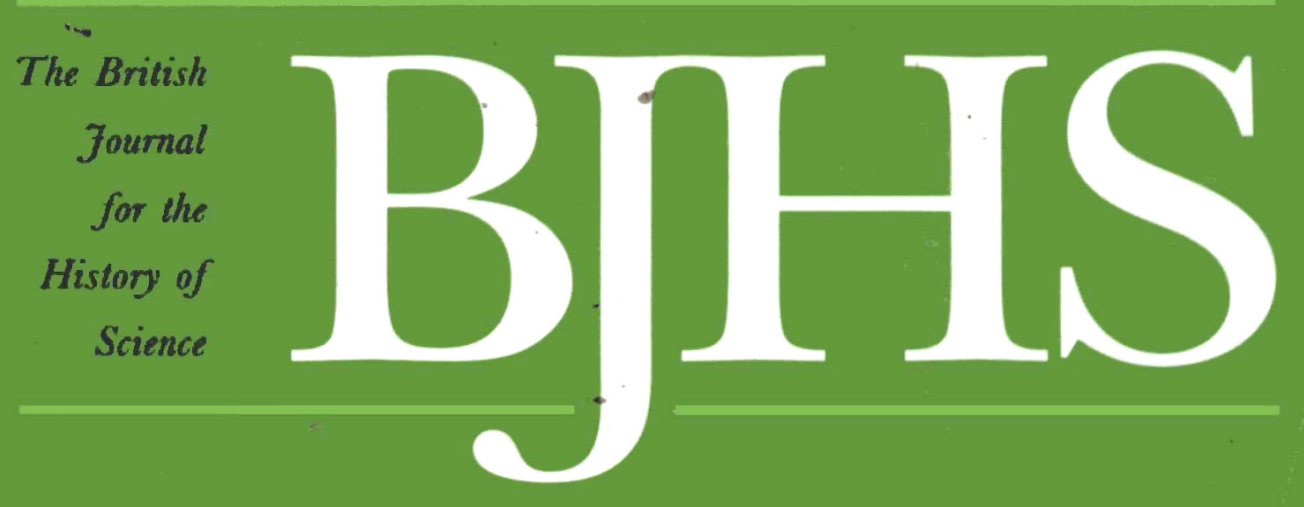

\title{
Organic Chemistry and High Technology, 1850-1950
}

Volume 25 Part , No. 84

ISSN Published for The British Society for the Histary of Science $0007-0.874$ by Cambridge University Press 
John Brooke Editor

Dept. of History

Furness College

University of Lancaster

Lancaster LAl 4YG

Robert Bud

Science Museum

South Kensington

London SW7 2DD

Tore Frangsmyr

Office for History of Science

Uppsala University

Box 256, S-751 05 Uppsala

Sweden

Owen Hannaway

Dept. of History of Science

The Johns Hopkins University

Gilman Hall

Baltimore, Maryland 21218

USA
John Henry

(Book Review Editor)

Science Studies Unit

University of Edinburgh

34 Buccleuch Place

Edinburgh EH8 9JT

Michael Hunter

Dept. of History

Birkbeck College

University of London

London WClE 7HX

Ludmilla Jordanova

Dept. of History

University of Essex

Wivenhoe Park

Colchester CO4 3SQ

David Lindberg

Dept. of History of Science

Helen C. White Hall 4143

University of Wisconsin

Madison, Wisconsin 53706

USA
Giuliano Pancaldi

Dept. of Philosophy

University of Bologna

Via Zamboni 38

40126 Bologna

Italy

Michael Shortland

Dept. of History and

Philosophy of Science

University of Sydney

Sydney NSW 2006

Australia

Charles Webster

All Souls College

Oxford OXI 4AL

Richard Yeo

Dept. of Humanities

Griffith University

Nathan

Brisbane

Queensland

Australia 4111

Contributions are welcome and should be sent to the Editor. They are considered on the understanding that they are unpublished and are not on offer to another journal. Two copies should be submitted, typed in double-spacing with a margin on A4 or American quarto paper. Include an abstract of 150-200 words. Quotations when long should be inset; when short, in single quotation marks. Spelling should follow the Oxford English Dictionary, and arrangement H. Hart, Rules for Compositors, Oxford, many edns. Be clear and consistent.

All papers should be rigorously documented, with references to primary and secondary sources typed separately from the text in double spacing, and numbered consecutively. Cite as follows:

1 B. Smetov and D. Blogski, Chemistry in the Eighteenth Century, 2nd edn (tr. R. Roe), 5 vols., Edinburgh, 1896-1914, iii, 237-8. Only cite the publisher for good reason.

2 J. Doe, 'Searching for gravity waves', in The History of Physics (ed. A. Burn and Z. Trent), Oxford, 1982, 22-9 (subsequent references may be written: 3 Doe, op. cit. (2), 23-4).

4 N. Brown, 'Developments of the cathode ray', Joumal of Physics (1972), 7, 31-5. Abbreviated journal titles may be given where these are in common use.

Standard works such as $D N B, D S B$, may be cited thus. For theses, cite University Microfilm order number, or at least Dissertations Abstract number. Line drawings should be drawn boldly in black ink on stout white paper, feintruled graph paper or tracing paper. Photographs should be glossy prints of good contrast and well matched for total range. The place of an illustration should be indicated in the margin of the text and a text reference given. Each illustration must carry the name of the author and article, its number, and a caption. Xerox copies may be sent when the article is first submitted for consideration.

(C) British Society for the History of Science. The British Society for the History of Science retains copyright for all articles published : it is the author's responsibility to secure any necessary permission for publication. Single copies of articles may be made for research or private study without further ado. Permission to make multiple copies should be obtained from the Society. Authors will receive twenty-five offprints of articles free. The editor cannot accept responsibility for loss of a typescript, but will take every care of it; typescripts are not normally returned to authors. In all matters concerning the publication of the article, the Editor's decision is final.

Subscriptions: The British Joumal for the History of Science (ISSN : 0007-0874) is published quarterly in March, June, September and December. The subscription price of Volume 25, 1992, is $€ 68$ net (USA and Canada US \$125) post free; single parts cost $£^{19}$ net (USA and Canada US \$33) plus postage. Four parts form a volume. Orders, which must be accompanied by payment, may be sent to any bookseller, subscription agent or to the publisher: Cambridge University Press, The Edinburgh Building, Shaftesbury Road, Cambridge CB2 2RU or in the USA and Canada to Cambridge Lniversity Press, The Journals Department, 40 West 20th Street, New York, NY 10011-4211, USA. Copies of the journal for subscribers in the USA and Canada are sent by air to New York to arrive with minimum delay. Second-class postage paid at New York, NY and at additional mailing offices. POSTMASTER: send address changes in USA and Canada to The British Joumal for the History of Science, Cambridge University Press, 110 Midland Avenue, Port Chester NY 10573-9864.

Claims for missing issues should be made immediately on receipt of the subsequent issue. 


\title{
The British \\ Journal \\ for the \\ History of \\ Science
}

March 1992

\section{Organic Chemistry and High Technology, 1850-1950}

\author{
A special issue \\ Guest Editors: Anthony S. Travis, Willem J. \\ Hornix and Robert Bud
}

1 John J. Beer: Foreword

5 Johan Schot: Technology in decline: a search for useful concepts. The case of the Dutch madder industry in the nineteenth century

27 Anthony S. Travis: Science's powerful companion: A. W. Hofmann's investigation of aniline red and its derivatives

45 Henk van den Belt: Why monopoly failed: the rise and fall of Société La Fuchsine

65 Willem J. Hornix: From process to plant: innovation in the early artificial dye industry

91 Ernst Homburg: The emergence of research laboratories in the dyestuffs industry, 1870-1900

113 Peter Reed: The British chemical industry and the indigo trade

127 Robert Bud: The zymotechnic roots of biotechnology

145 Peter J. T. Morris: The technology-science interaction: Walter Reppe and cyclooctatetraene chemistry 